\title{
FINANCIAL PERFORMANCE RANKING OF AIRLINES IN THE COVID-19 ERA
}

\section{DOI: 10.17261/Pressacademia.2021.1503 \\ PAP- V.14-2021(29)-p.121-122}

\author{
DilekTeker ${ }^{1}$, Suat Teker ${ }^{2}$, Melike Cobandag ${ }^{3}$ \\ ${ }^{1}$ Isik University, Department of Management, Istanbul, Turkey. \\ dilek.teker@isikun.edu.tr, ORCID: 0000-0002-3893-4015 \\ ${ }^{2}$ Isik University, Department of Management, Istanbul, Turkey. \\ suat.teker@isikun.edu.tr, ORCID: 0000-0002-7981-3121 \\ ${ }^{3}$ Isik University, Department of Management, Istanbul, Turkey. \\ melike.cobandag@isikun.edu.tr, ORCID: 0000-0002-8020-6783
}

\section{To cite this document}

Teker, D., Teker, S., Cobandag, M., (2021). Financial performance ranking of airlines in the covid-19 era. PressAcademia Procedia (PAP), 14, 121-122.

Permemant link to this document: http://doi.org/10.17261/Pressacademia.2021.1503

Copyright: Published by PressAcademia and limited licenced re-use rights only.

\section{ABSTRACT}

Purpose- The purpose of this study is to give rankings of the top 20 airlines in the world according to some financial performance indicators for the time period between years 2018 and 2020. Additionally, this study will highlight some of the financial performance indicators of this top 20 airline companies during the COVID-19 era in 2020. Airline industry is very important for modern society and it has a crucial role for globalization and businesses by connecting regions, promoting global trade and tourism and hence enabling economic and social development. Over the last two decades, the troubled airline companies were often on news delebrating financial difficulties, layouts and distrupted scheduled flights. Many well-known airline companies needed financial rescue and either received government fundings or seeked consolidation or a partnership. COVID-19 also had a crucial impact on the deterioration of the airline industry due to quarantinas and shutdowns for travel and business. Because of these reasons, it is very important to see the rankings of the top 20 airlines in the world and indicate some of the financial performance measures of these companies during the COVID-19 era.

Methodology- In this study, first the top 20 airlines of the world was listed by ranking the 111 public airline companies in the world according to their total assets in 2020. The data was gathered from the REUTERS database. From again the REUTERS database, total assets, total equity, total revenue, net income, total short-term liabilities and total long-term liabilities of this 20 airline companies was obtained in terms of USD for the period between years 2018 and 2020. In addition, the number of employees and the number of aircrafts data was gathered to show some operational indicators of these same airline companies for the same term. Then the rankings of this top 20 airline companies was made considering all of these indicators and the change in the place of the rankings of airlines between years 2018 and 2020 was indicated. In this study, it was also showed whether the ranking of the airline companies according to financial performance differed in the COVID-19 era in 2020.

Findings- The analysis of this study reveals that although the largest asset size was reported by Delta Airlines in 2020 , the highest revenue was generated by American Airlines. On the other hand, the highest number of aircrafts were employed by American Airlines in 2018,2019 and 2020, whereas the highest number of employees worked for Lufthansa in the same years. Although American Airlines reported to gain the highest amount of total revenues in 2020; Cathay Pacific Airlines was ranked as the number one airline company in the same year if revenue per employee and if revenue per aircraft were considered as the performance criteria. None of these airlines was ranked as one of the top three performers considering net income for the year 2020, which was the COVID-19 era. The change in the rankings of the top 20 airlines according to net income in 2020 clearly showed that in the COVID-19 era, the financial performance of the airline companies was hit hard by the economic shutdowns.

Conclusion- Based upon the findings of the analysis, it may be concluded that different financial indicators must be considered together instead of solely considering total assets, total revenues or net income to analyze financial performance of the airline companies. As it was also stated by the related literature, both operational and financial indicators are important in the performance measurement of airline companies. The financial performance of the airline companies influences short and long term company decisions as well as it shapes strategic planning. Hence, a comprehensive financial performance measurement must be employed in strategic planning of airline companies.

Keywords: Airlines, financial performance ranking, COVID-19 era

JEL Codes: G10, G20, G22 


\section{REFERENCES}

Abdi, Y., Li, X., \& Càmara-Turull, X. (2020). Impact of sustainability on firm value and financial performance in the air transport industry. Sustainability, 12, 366-379.

Alan, Y., \& Lapré, M. A. (2018). Investigating operational predictors of future financial distress in the US airline industry. Production and Operations Management, 27(4), 734-755.

Baydar, B., \& Dursun, G. D. (2019). An application of risk management on airline industry via financial ratios and artificial intelligence. International Journal of Business and Applied Social Science, 5(6), 668-681.

Dağlı, D. (2021). Havayolu işletmelerinin Covid-19 öncesi ve Covid-19 sürecindeki finansal performanslarının Topsis yöntemi ile değerlendirilmesi. İşletme Araştırmaları Dergisi, 13(3), 2242-2255.

Feng, C. M., \& Wang, R. T. (2000). Performance evaluation for airlines including the consideration of financial ratios. Journal of Air Transport Management, 6(3), 133-142.

Gole, I., Dobrea, R. C., \& Gombos, C. C. (2021). Aviation industry-challenges and uncertainties after the Covid-19 pandemic. In SHS Web of Conferences (Vol. 92). EDP Sciences.

Huang, C. C. (2021). Assessing the financial performance of airlines in the Asia-Pacific region. Investment Management and Financial Innovations, 18(2), 234-244.

Kalemba, N., \& Campa-Planas, F. (2019). Safety and the economic and financial performance in the airline industry: is there any relationship? Aviation, 23(1), 7-14.

Kiracı, K., \& Bakır, M. (2020). Evaluation of airlines performance using an integrated critic and codas methodology: The case of star alliance member airlines. Studies in Business and Economics, 15(1), 83-99.

Kiraci, K., \& Yaşar, M. (2020). The determinants of airline operational performance: an empirical study on major world airlines. Sosyoekonomi, 28(43), 107-117.

Lee, J. (2019). Effects of operational performance on financial performance. Management Science Letters, 9(1), 25-32.

Lee, S., Kim, H., \& Lee, N. (2019). A comparative analysis of financial and operational performance pre-and post-IPO: with a focus on airline companies. Academy of Accounting and Financial Studies Journal, 23(3), 1-14.

Nasir, A. M., Ahmed, A., \& Barkat, W. (2017). Operational performance and financial performance of Malaysia Airlines. Paradigms, 11(1), 3440.

Rababah, A., Al-Haddad, L., Sial, M. S., Chunmei, Z., \& Cherian, J. (2020). Analyzing the effects of COVID-19 pandemic on the financial performance of Chinese listed companies. Journal of Public Affairs, 20(4), e2440.

Rosini, I. \& Gunawan, J. (2018). Financial ratio and performance airlines industry with DEA and TOPSIS model. International Journal of Pure and Applied Mathematics, 119(10), 367-374.

Suhardjanto, D., \& Ajibroto, N. (2017). Ownership structure and financial performance: an empirical study of listed airlines industry in Asia and Australia. Review of Integrative Business and Economics Research, 6(1), 121-130.

Wang, Y. J. (2008). Applying FMCDM to evaluate financial performance of domestic airlines in Taiwan. Expert Systems with Applications, 34(3), 1837-1845.

Zhang, Q., Koutmos, D., Chen, K., \& Zhu, J. (2021). Using operational and stock analytics to measure airline performance: A network DEA approach. Decision Sciences, 52(3), 720-748. 